\title{
Effect of Supplementation of Various Sources of Methionine on Growth Performance and Cost Economics in Broiler Chicken
}

\author{
B. Brahmaiah ${ }^{1 *}$, J.V. Ramana ${ }^{2}$, B. Devasena ${ }^{3}$ and G. Vijay Bhaskar Reddy ${ }^{4}$ \\ ${ }^{1}$ Department of Animal Nutrition, ${ }^{2}$ Controller of Examinations, ${ }^{3}$ Department of Livestock \\ Farm Complex, ${ }^{4}$ Department of Livestock Products Technology, College of Veterinary \\ Science, Tirupati, Sri Venkateswara Veterinary University, \\ Chittoor District, Andhra Pradesh, India \\ *Corresponding author
}

Keywords

Synthetic Methionine,

Methionine producing

microbes (MPM), Broiler

chicken, Growth

performance, Cost

economics

Article Info

Accepted:

07 October 2018

Available Online:
10 November 2018

\section{A B S T R A C T}

An experiment was conducted to study the effect of various sources of Methionine on growth performance and cost economics in broiler chicken. In a CRD model, 375 broiler chicks (Vencobb) were randomly divided into five groups $\left(T_{1}, T_{2}, T_{3}, T_{4}\right.$ and $\left.T_{5}\right)$, each containing 3 replicates with 25 birds in each replicate. The $T_{1}$ group served as control group, $T_{2}$ group was supplemented with synthetic Methionine (Nutrient requirements of ICAR 2013), $T_{3}$ and $T_{4}$ groups were supplemented with Methionine producing microbes (MPM) and $\mathrm{T}_{5}$ group was supplemented with combination of $\mathrm{T}_{2}$ and $\mathrm{T}_{3}$, respectively for a period of 42 days. The results of the experiment revealed a significant $(\mathrm{P}<0.01)$ improvement in body weight gain, better feed efficiency and lower feed cost per $\mathrm{kg}$ live body weight gain in synthetic Methionine $\left(\mathrm{T}_{2}\right)$ supplemented group compared to the other groups during the entire experimental period. However, no significant difference was observed among all the five groups with respect to feed intake. No signs of mortality were observed among all the five groups during the entire experimental period.

\section{Introduction}

The Poultry Industry has emerged as the fastest growing segment of the livestock sector globally due to a number of favorable reasons. Among all essential amino acids Lysine and Methionine are considered as critical amino acids (FAO, 2010). Methionine acts as a lipotropic agent through its role as an amino acid in balancing protein and as methyl donor and is involved in the metabolism of Choline, Betaine, Folic acid and Vitamin $\mathrm{B}_{12}$ (Young et al., 1955; March and Biely, 1956). The most common source of Methionine in poultry diets is DL-Met produced by synthetic chemistry from acrolein, methyl mercaptan and hydrogen cyanide. The synthetic Methionine can be metabolized into highly toxic 
compounds such as methyl thiopropionate, thereby adversely altering the performance of poultry birds (Baker, 1991). Similarly, Methionine producing microbes have been isolated from soil and from various sources and screened for the amount of Methionine produced from the microorganisms (Thomas, 2014).

Keeping in view, the present investigation was carried out to study the effect of Methionine producing microbes (Bacillus subtilis, Corynebacterium glutamicum, Lactobacillus plantarum, Leuconostoc sp., Saccharomyces sake) live microbial cultures with a TVC of 6000 Million CFU/g. and synthetic Methionine in broiler diets. Methionine producing microbes (MPM) is an commercial by product supplied by M/s DVS BIOLIFE Pvt Ltd.

\section{Materials and Methods}

\section{Experimental location}

The present experiment was carried out at Livestock Farm Complex, College of veterinary science Tirupati, Sri Venkateswara Veterinary University, Andhra Pradesh.

\section{Experimental design}

The present study was carried out with three hundred and seventy five, day old broiler chicks obtained from a local hatchery. These chicks were randomly allotted to five experimental groups with each group having three replicates and with twenty five birds per replicate in a Completely Randomized Design. The $\mathrm{T}_{1}$ group served as control group, $\mathrm{T}_{2}$ group was supplemented with synthetic Methionine (Nutrient requirements of ICAR, 2013) $T_{3}$ and $T_{4}$ group were supplemented with MPM and the $\mathrm{T}_{5}$ group was supplemented with combination of $T_{2}$ and $T_{3}$ (half the dose of $T_{2}$ and $T_{3}$ ) respectively for a period of 42 days was presented in the Table 1.

\section{Chemical composition of experimental diets}

The broiler diets were formulated in three phases i.e., pre-starter (0-14 days), starter (1528 days) and finisher (29-42 days). Basal diet was prepared as per the Nutrient requirements of Poultry ICAR (2013). Representative samples of experimental diets were analyzed for proximate composition as per AOAC (2005) presented in the Tables 2, 3 and 4 respectively. The ME values for all feed ingredients was estimated using equation suggested by NRC poultry (1994).

\section{Health management}

The chicks were vaccinated with HVT vaccine, $F_{1}$ vaccine, IBD vaccine and Lasota vaccine on the $1^{\text {st }}, 6^{\text {th }}, 14^{\text {th }}$ and $23^{\text {rd }}$ days respectively.

\section{Parameters studied}

The individual body weight of the birds was recorded at weekly interval and calculated phase wise upto 42 days of age. Weekly feed consumption and feed efficiency was recorded in every group and calculated phase wise. The relative cost economics of raising broilers up to six weeks of age with synthetic Methionine and MPM was calculated based on the present input costs, live weight gains and prevailing market price of broilers.

\section{Analysis of data}

The data obtained was subjected to one- way ANOVA. Differences between means were tested at the $1 \%$ probability level using Duncan's LSD test. All the statistical analysis were done using SPSS programmer version 16 (SPSS, Richmond, VA, USA) as described by DYtham (2011). 


\section{Results and Discussion}

The results of the current study revealed, no significant differences $(\mathrm{P}>0.05)$ in feed intake during entire experimental period (Table 5). The results were not in agreement with Nagaraj naik et al., (2014) who reported that, the feed consumption was better in Methionine producing probiotics supplemented group than in synthetic Methionine supplemented group.

In this study, significant $(\mathrm{P}>0.01)$ improvement in body weight gain in broiler chicks supplemented with synthetic Methionine compared with other groups of chicks (Table 6). This may be attributed due to $99 \%$ bioavailability of Methionine in the body. Synthetic Methionine appears to be absorbed faster by the intestinal epithelium than dietary protein-bound amino acids (Batterham and Murison, 1981; Cowey and Walton, 1988 and Zarate and Lovell, 1999). The present findings were similar to the Lgbasan and Olugosi (2013) reported that improved body weight gains in broilers supplemented with herbal and synthetic Methionine than control group. Significantly $(\mathrm{P}<0.01)$ better feed efficiency was observed in synthetic Methionine supplemented group compared to other groups (Table 7). This might be due to improved amino acid balance which might have promoted growth performance by enhancing feed efficiency and increasing protein synthesis as well as better feed efficiency in birds (Binder, 2003). Similar to the present findings, Halder and Roy (2007) reported that, better feed efficiency was noticed in both herbal and synthetic Methionine supplemented groups.

Table.1 Inclusion levels of synthetic Methionine, MPM and combination (gram/ton of feed) at various phases of growth in broiler chicken

\begin{tabular}{|l|c|c|c|c|c|}
\hline \multicolumn{1}{|c|}{ Phases } & $\mathrm{T}_{1}$ & $\mathrm{~T}_{\mathbf{2}}$ & $\mathrm{T}_{3}$ & $\mathrm{~T}_{4}$ & $\mathbf{T}_{\mathbf{5}}\left(\mathbf{T}_{2}+\mathbf{T}_{3}\right)$ \\
\hline Pre-starter (0-14 days) & - & 2000 & 500 & 1000 & $1000+250$ \\
\hline Starter (15-28 days) & - & 1700 & 500 & 1000 & $850+250$ \\
\hline Finisher (29-42 days) & - & 1300 & 500 & 1000 & $650+250$ \\
\hline
\end{tabular}

Table.2 Chemical composition (\% DMB) of Broiler Pre-starter diet

\begin{tabular}{|c|c|c|c|c|c|}
\hline Nutrient & $\mathrm{T}_{1}$ & $\mathrm{~T}_{2}$ & $\mathrm{~T}_{3}$ & $\mathrm{~T}_{4}$ & $\mathrm{~T}_{5}$ \\
\hline Dry matter & 90.28 & 90.12 & 90.19 & 90.17 & 90.15 \\
\hline Crude protein & 21.94 & 22.09 & 21.94 & 21.95 & 22.01 \\
\hline Crude fat & 6.14 & 6.19 & 6.08 & 6.11 & 6.13 \\
\hline Crude Fiber & 6.08 & 6.05 & 6.10 & 6.03 & 6.10 \\
\hline Total ash & 10.24 & 10.18 & 10.15 & 10.09 & 10.11 \\
\hline Acid insoluble ash & 2.18 & 2.13 & 2.08 & 2.17 & 2.15 \\
\hline NFE & 55.60 & 55.49 & 55.73 & 55.82 & 55.65 \\
\hline Calcium & 1.01 & 1.02 & 1.02 & 1.02 & 1.02 \\
\hline A vailable P & 0.7 & 0.66 & 0.63 & 0.66 & 0.63 \\
\hline Lysine* & 1.21 & 1.20 & 1.21 & 1.21 & 1.20 \\
\hline Methionine* & 0.31 & 0.48 & 0.31 & 0.31 & 0.395 \\
\hline MIE (K.Cal/Kg)* & 3000 & 3001 & 2999 & 2998 & 3000 \\
\hline *cled
\end{tabular}


Table.3 Chemical composition (\% DMB) of Broiler Starter diet

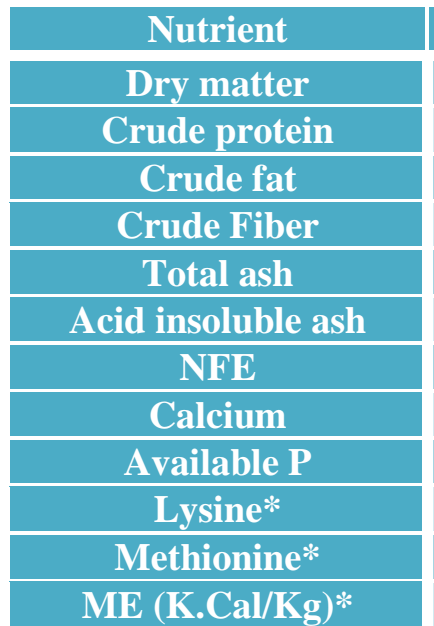

\begin{tabular}{|c|c|c|c|c|}
\hline $\mathrm{T}_{1}$ & $\mathrm{~T}_{2}$ & $\mathrm{~T}_{3}$ & $\mathrm{~T}_{4}$ & $\mathrm{~T}_{5}$ \\
\hline 90.82 & 90.72 & 90.76 & 90.83 & 90.68 \\
\hline 21.48 & 21.54 & 21.50 & 21.50 & 21.51 \\
\hline 6.25 & 6.18 & 6.31 & 6.19 & 6.17 \\
\hline 6.14 & 6.09 & 6.17 & 6.11 & 6.12 \\
\hline 10.52 & 10.51 & 10.48 & 10.55 & 10.47 \\
\hline 2.25 & 2.21 & 2.28 & 2.29 & 2.25 \\
\hline 55.61 & 55.68 & 55.54 & 55.65 & 55.73 \\
\hline 1.01 & 1.01 & 1.02 & 1.01 & 1.01 \\
\hline 0.7 & 0.58 & 0.46 & 0.58 & 0.46 \\
\hline 1.08 & 1.07 & 1.08 & 1.08 & 1.07 \\
\hline 0.31 & 0.48 & 0.31 & 0.31 & 0.395 \\
\hline 3049 & 3050.3 & 3048 & 3047 & 3049.2 \\
\hline
\end{tabular}

*calculated values

Table.4 Chemical composition (\% DMB) of Broiler Finisher diet

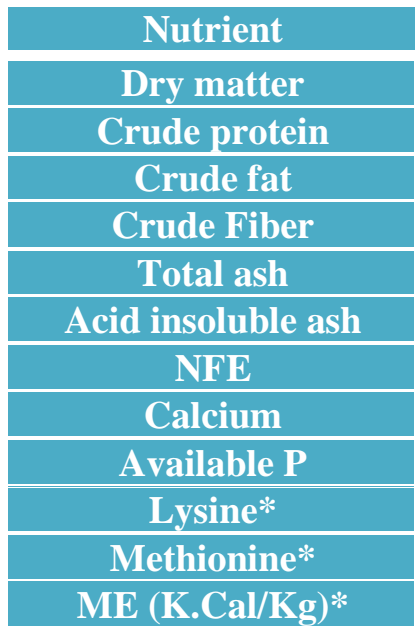

\begin{tabular}{|c|c|c|c|c|}
\hline $\mathrm{T}_{1}$ & $\mathrm{~T}_{2}$ & $\mathrm{~T}_{3}$ & $\mathrm{~T}_{4}$ & $\mathrm{~T}_{5}$ \\
\hline 91.66 & 91.58 & 91.69 & 91.59 & 91.66 \\
\hline 19.47 & 19.52 & 19.48 & 19.47 & 19.49 \\
\hline 6.37 & 6.29 & 6.35 & 6.34 & 6.33 \\
\hline 6.23 & 6.28 & 6.27 & 6.21 & 6.19 \\
\hline 10.76 & 10.71 & 10.75 & 10.68 & 10.69 \\
\hline 2.47 & 2.41 & 2.49 & 2.44 & 2.51 \\
\hline 57.17 & 57.20 & 57.15 & 57.30 & 57.30 \\
\hline 1.07 & 1.09 & 1.01 & 1.08 & 1.09 \\
\hline 0.69 & 0.57 & 0.45 & 0.57 & 0.45 \\
\hline 0.94 & 0.93 & 0.94 & 0.94 & 0.92 \\
\hline 0.28 & 0.41 & 0.28 & 0.28 & 0.345 \\
\hline 3099 & 3102 & 3099 & 3099 & 3099 \\
\hline
\end{tabular}

*calculated values

Table.5 The Mean \pm SE and analysis of variance of feed intake (g) of broilers supplemented with various sources of Methionine in diet

\begin{tabular}{|c|c|c|c|c|c|}
\hline Phases & $\mathrm{T}_{1}$ & $\mathrm{~T}_{2}$ & $\mathrm{~T}_{3}$ & $\mathrm{~T}_{4}$ & $\mathrm{~T}_{5}$ \\
\hline Pre- Starter & 555.23 & 520.89 & 532.31 & 535.28 & 545.72 \\
(0-14 days) & \pm 3.88 & \pm 3.28 & \pm 5.15 & \pm 5.26 & \pm 6.44 \\
\hline Starter & 1168.43 & 1173.75 & 1158.20 & 1163.18 & 1178.28 \\
\hline (15-28 days) & \pm 2.32 & \pm 5.64 & \pm 4.04 & \pm 3.05 & \pm 2.04 \\
\hline Finisher & 1735.40 & 1728.19 & 1738.94 & 1725.58 & 1732.30 \\
\hline (29-42 days) & \pm 5.34 & \pm 3.63 & \pm 2.93 & \pm 4.39 & \pm 5.27 \\
\hline Total & 3433.01 & 3429.83 & 3425.45 & 3420.04 & 3431.32 \\
$(\mathbf{0}-\mathbf{4}$ days $)$ & \pm 5.48 & \pm 4.81 & \pm 4.49 & \pm 2.87 & \pm 3.11 \\
\hline
\end{tabular}

NS- Non-significant 
Table.6 The Mean \pm SE and analysis of variance of body weight gain (g) of broilers supplemented with various sources of Methionine in diet

\begin{tabular}{|c|c|c|c|c|c|}
\hline Phases** & $\mathrm{T}_{1}$ & $\mathrm{~T}_{2}$ & $\mathrm{~T}_{3}$ & $\mathrm{~T}_{4}$ & $\mathrm{~T}_{5}$ \\
\hline Pre-starter & 244.52 & 325.21 & 256.97 & 252.83 & 296.46 \\
(0-14 days) & $\pm 0.53^{\mathrm{e}}$ & $\pm 0.09^{\mathrm{a}}$ & $\pm 0.98^{\mathrm{c}}$ & $\pm 0.41^{\mathrm{d}}$ & $\pm 0.78^{\mathrm{b}}$ \\
\hline Starter & 619.41 & 821.92 & 641.37 & 625.64 & 755.87 \\
\hline (15-28 days) & $\pm 0.50^{\mathrm{e}}$ & $\pm 0.93^{\mathrm{a}}$ & $\pm 0.04^{\mathrm{c}}$ & $\pm 0.15^{\mathrm{d}}$ & $\pm 0.81^{\mathrm{b}}$ \\
\hline Finisher & 801.79 & 878.02 & 899.51 & 808.37 & 849.20 \\
\hline (29-42 days) & $\pm 0.19^{\mathrm{e}}$ & $\pm 0.54^{\mathrm{b}}$ & $\pm 0.98^{\mathrm{a}}$ & $\pm 0.09^{\mathrm{d}}$ & $\pm 0.25^{\mathrm{c}}$ \\
\hline Total & 1665.74 & 2025.15 & 1797.86 & 1685.84 & 1901.52 \\
$(\mathbf{0}-42$ days $)$ & $\pm 0.25^{\mathrm{e}}$ & $\pm 0.54^{\mathrm{a}}$ & $\pm 0.79^{\mathrm{c}}$ & $\pm 0.40^{\mathrm{d}}$ & $\pm 0.64^{\mathrm{b}}$ \\
\hline
\end{tabular}

${ }^{\text {abcde }}$ Values in a row bearing different superscripts differ significantly $* *(\mathrm{P}<0.01)$

Table.7 The Mean \pm SE and analysis of variance of feed efficiency of broilers supplemented with various sources of Methionine in diet

\begin{tabular}{|l|l|l|l|l|l|}
\hline Phases*** & $\mathrm{T}_{1}$ & $\mathrm{~T}_{2}$ & $\mathrm{~T}_{3}$ & $\mathrm{~T}_{4}$ & $\mathrm{~T}_{5}$ \\
\hline Pre-starter & 2.27 & 1.60 & 2.07 & 2.12 & 1.82 \\
$(\mathbf{0}-14$ days $)$ & $\pm 0.10^{\mathrm{a}}$ & $\pm 0.03^{\mathrm{d}}$ & $\pm 0.06^{\mathrm{b}}$ & $\pm 0.12^{\mathrm{b}}$ & $\pm 0.07^{\mathrm{c}}$ \\
\hline Starter & 1.86 & 1.42 & 1.79 & 1.86 & 1.55 \\
$(\mathbf{1 5 - 2 8}$ days $)$ & $\pm 0.04^{\mathrm{a}}$ & $\pm 0.11^{\mathrm{c}}$ & $\pm 0.08^{\mathrm{a}}$ & $\pm 0.03^{\mathrm{a}}$ & $\pm 0.10^{\mathrm{b}}$ \\
\hline Finisher & 2.16 & 1.96 & 1.93 & 2.12 & 2.04 \\
$(\mathbf{2 9 - 4 2}$ days $)$ & $\pm 0.12^{\mathrm{a}}$ & $\pm 0.17^{\mathrm{c}}$ & $\pm 0.09^{\mathrm{c}}$ & $\pm 0.11^{\mathrm{a}}$ & $\pm 0.14^{\mathrm{b}}$ \\
\hline Total & 2.09 & 1.66 & 1.93 & 2.04 & 1.80 \\
$(\mathbf{0}-\mathbf{4 2}$ days $)$ & $\pm 0.18^{\mathrm{a}}$ & $\pm 0.13^{\mathrm{d}}$ & $\pm 0.11^{\mathrm{b}}$ & $\pm 0.09^{\mathrm{a}}$ & $\pm 0.15^{\mathrm{c}}$ \\
\hline
\end{tabular}

abcde Values in a row bearing different superscripts differ significantly** $(\mathrm{P}<0.01)$

Table.8 The Mean \pm SE and analysis of variance of cost economics of broilers supplemented with various sources of Methionine in diet

\begin{tabular}{|c|c|c|c|c|c|}
\hline & $\mathbf{T}_{1}$ & $\mathbf{T}_{2}$ & $\mathbf{T}_{3}$ & $\mathbf{T}_{4}$ & $\mathbf{T}_{5}$ \\
\hline $\begin{array}{l}\text { Avg. Feed intake } \\
\text { per bird for } 42 \\
\text { days of age }{ }^{N S}(g) \\
\end{array}$ & $\begin{array}{l}3433.01 \\
\pm 5.48\end{array}$ & $\begin{array}{l}3429.83 \\
\pm 4.81\end{array}$ & $\begin{array}{l}3425.45 \\
\pm 4.49\end{array}$ & $\begin{array}{l}3420.04 \\
\pm 2.87\end{array}$ & $\begin{array}{l}3431.32 \\
\pm 3.11\end{array}$ \\
\hline $\begin{array}{l}\text { Cost of feed/ bird } \\
\text { NS }\end{array}$ & $\begin{array}{l}100.62 \\
\pm 1.23\end{array}$ & $\begin{array}{l}102.49 \\
\pm 0.97\end{array}$ & $\begin{array}{l}101.03 \\
\pm 1.54\end{array}$ & $\begin{array}{l}101.43 \\
\pm 1.11\end{array}$ & $\begin{array}{l}101.86 \\
\pm 0.89\end{array}$ \\
\hline Weight gain*** (g) & $\begin{array}{l}1665.74 \\
\pm 0.25^{\mathrm{e}}\end{array}$ & $\begin{array}{l}2025.15 \\
\pm 0.54^{\mathrm{a}}\end{array}$ & $\begin{array}{l}1797.86 \\
\pm 0.79^{c}\end{array}$ & $\begin{array}{l}1685.84 \\
\pm 0.40^{d}\end{array}$ & $\begin{array}{l}1901.52 \\
\pm 0.64^{\mathrm{b}}\end{array}$ \\
\hline $\begin{array}{l}\text { Feed cost per } \mathrm{Kg} \\
\text { live weight gain } * * * \\
\text { (Rs.) }\end{array}$ & $\begin{array}{l}61.25 \\
\pm 0.84^{\mathrm{a}}\end{array}$ & $\begin{array}{l}49.61 \\
\pm 0.79^{d}\end{array}$ & $\begin{array}{l}56.93 \\
\pm 0.68^{b}\end{array}$ & $\begin{array}{l}60.50 \quad \pm \\
0.77^{\mathrm{a}}\end{array}$ & $\begin{array}{l}53.44 \\
\pm 0.69^{c}\end{array}$ \\
\hline
\end{tabular}


The feed cost per $\mathrm{Kg}$ live weight gain was significantly $(\mathrm{P}<0.01)$ low in birds fed diets with synthetic Methionine (Rs. 49.61) as compared to other groups (Table 8). The results were in agreement with Halder and Roy (2007) reported that, cost benefit ratio was found to be significantly and economically viable in diet with DL Methionine or herbal-Methionine treated groups than control group.

Based on the present results it can be concluded that dietary supplementation of synthetic Methionine had significant impact on better growth performance and cost economics compared to MPM treated groups and control group.

\section{References}

AOAC, 2005. Official Methods of Analysis of the Association of Official Analytical Chemists. $15^{\text {th }}$ Edition, Washington, D.C.

Baker, D. H. 1991. Amino acid tolerances of swine and poultry. Washington, DC: NFIA. Nutrition Institute handbook.

Batterham, E. S. and Murison, R. D. 1981. Utilization of free lysine by growing pigs. British Journal of Nutrition. 46:87-92.

Binder, M. 2003. Life cycle analysis of DLmethionine in broiler meat production. Amino News, Information for the feed industry. Degussa feed additives, Hanau-Wolfgang, Germany: 1-8.

Cowey, C. B. and Walton, M. J. 1988. Studies on the uptake of (14C) amino acids derived from both dietary (14C) protein and dietary (14C) amino acids by rainbow trout, Salmogairdneri Richardson. Journal of Fish Biology. 33: 293-305.

DYtham, C. 2011. Choosing and Using Statistics: A Biologist's Guide. 3rd edition. Whiley-Blackwell Ltd., London, UK.

FAO 2010. Smallholder Poultry Production Livelihoods, Food Security and Sociocultural Significance, by K. N. Kryger, K. A. Thomsen, M. A. Whyte and M. Dissing. FAO Smallholder Poultry Production Paper No. 4. Rome.

Halder, G. and Roy, B. 2007. Effect of herbal or synthetic methionine on performance, cost benefit ratio, meat and feather quality of broiler chicken. International Journal of Agricultural Research. 2: 987-996.

Lgbasan, F.A. and Olugosi, O.A. 2013. Performance characteristics, biochemical and haematologcal profiles of broiler chickens fed synthetic and herbal methionine supplemented diets. African Journal of Food Science. 7(6): pp. 159-167.

March, B. and Biely, J. 1956. Folic acid supplementation of high protein-high fat diets. Poultry Science. 35: 550-551.

Nagaraj Naik., Jaishankar, N., Udaykumar, N., Mathad, P. F., Ambarish, G. and Nanda, S. K. 2014. Isolation, screening and evaluation of methionine producing probiotics on production performance of giriraja chicks. International Conference on Food, Biological and Medical Sciences. Jan. 28-29.

National Research Council (NRC). 1994. Nutrient Requirements of Poultry. $9^{\text {th }}$ Edition. National Academy Press, Washington DC, USA.

Thomas willke. 2014. Methionine production - a critical review. Applied Microbiology And Biotechnology. Springer-Verlag Berlin Heidelberg.

Young, R. J., Norris, L. C. and Heuser, G. F. 1955. The chick's requirement for folic acid in the utilization of choline and its precursors betaine and methyl amino ethanol. Journal of Nutrition. 55: 535-362. 
Zarate, D. D. and Lovell, R. T. 1999. Effects of feeding frequency and rate of stomach evacuation on utilization of dietary free and protein-bound lysine for growth by channel catfish (Ictalurus punctatus). Aquaculture Nutrition. 5:1722.

\section{How to cite this article:}

Brahmaiah, B., J.V. Ramana, B. Devasena and Vijay Bhaskar Reddy, G. 2018. Effect of Supplementation of Various Sources of Methionine on Growth Performance and Cost Economics in Broiler Chicken. Int.J.Curr.Microbiol.App.Sci. 7(11): 767-773. doi: https://doi.org/10.20546/ijcmas.2018.711.092 